\title{
Inspection of the Level of Effects of Service Quality to Customer Satisfaction in Retail Supermarkets
}

\author{
Nguyen Thi Hang ${ }^{1}$, Pham Minh Dat ${ }^{2}$, Nguyen Van Huan ${ }^{3}$, Truong Thi Viet Phuong ${ }^{4}$ \\ ${ }^{1}$ Faculty of Economic Information System, Thai Nguyen University of Information and Communication \\ Technology, Vietnam \\ ${ }^{2}$ Thuongmai University \\ ${ }^{3}$ Faculty of Economic Information System, Thai Nguyen University of Information and Communication \\ Technology, Vietnam \\ ${ }^{4}$ Information and Communication Technology Thai Nguyen University, Vietnam \\ nthang@ictu.edu.vn
}

\section{Abstract}

For every business dealing in goods and services, especially in the field of sales, attracting more and more buyers will help increase sales, contributing to achieving the ultimate goal of the producer. Profit maximization. Currently, retail supermarkets are facing fierce competition pressure among supermarket organizations: from the competition of existing supermarkets in the area, the chains of buffet goods, the shopping centers, the penetration of the "giants" in the domestic and foreign retail supermarket industry. In the context of consumers having more and more opportunities to choose shopping places and more and more requirements for service quality, especially, consumers when they come to supermarkets are not merely Buy the goods you need but also feel comfortable, feel your needs are best met. Therefore, when it comes to customer satisfaction with supermarkets, the issues that we need to pay attention to, from the quality of goods to the attitude of the staff, the promotions, as well as pay attention to customers' feelings about the service quality of the business, thereby taking measures to keep old customers, attract new customers ... All have certain effects on customer satisfaction in Supermarkets in general and at retail supermarkets in particular. This study uses exploratory factor analysis (EFA) and positive factor analysis (CFA) to test the scale of the influence of factors on customer satisfaction at the supermarket. The study has determined the scale of affecting factors including 7 components with 27 observed variables. The results of the study help to verify the qualitative statements about the impact of factors on customer satisfaction, thereby drawing conclusions and recommendations to help supermarkets promote points. Strong as well as improve weak points to achieve the best service quality.
Keywords

supermarket retail; cronbacksalpha testing, customer satisfaction; factors affecting purchasing power, $\mathrm{EA}$ discovery factor, CFAaffirmation

\section{Introduction}

Service quality is a matter of great concern to managers in the present business day. A product of good quality is not necessarily chosen by customers if the services associated with the product are underestimated. According to Feigenbaum (1991), "Quality is a customer's decision based on actual experience with the product or service, measured based on customer 
SIASAT Journal of Social, Cultural and Political Studies, 5 (1) January 2020, 36-46

ISSN: 2721-7469 (Print), 2721-7450 (Online)

Nguyen Thi Hang, Truong Thi Viet Phuong, Nguyen Thi Quynh Trang: Inspection of the Level of Effects of Service Quality to Customer Satisfaction in Retail Supermarkets

https://siasatiournal.com/index.php/siasat

requirements, these requirements can be stated or not stated, consciously or simply perceived, wholly subjective or professional and always representing dynamic goals in a competitive market".

According to Fornell (1995) satisfaction or frustration after consumption, is defined as the response of customers to judging by perceiving the difference between pre-consumption expectations and the actual perception of product after consuming it. Satisfaction level depends on the difference between the result received and the expectation, if the actual result is lower than the expectation then the customer is dissatisfied, if the actual result is similar commensurate with the expectation the customer will be satisfied, if the actual result is higher than the expectation the customer is very satisfied. Customer expectations are rooted in the shopping experience, friends, colleagues, and information from sellers and competitors.

There are many definitions of customer satisfaction. According to Philip Kotler, customer satisfaction is the degree to which a person's emotional state stems from a comparison of results obtained from the consumption of products / services with expectations. theirs. Kotler (2000), defines "Satisfaction as a feeling of satisfaction or frustration of a person by the result of comparing the actual received product (or result) in relation to expectations. waiting for them ". Hansemark and Albinsson (2004) state that "Customer satisfaction is an overall attitude of a customer to a service provider, or an emotion that responds to the difference between what the customer predicts. before and what they receive, in response to certain needs, goals or desires".

Research on the correlation between service quality and customer satisfaction has been interested by many researchers (Coronin \& Taylor, 1992; Kotler et al, 1999; Kim etal, 2005; Namkung \& Jang 2006; Nguyen \& Nguyen, 2003; Choi \& Chu, 2001; Pham \& Kullada, 2009). That has become the maxim for the service business in retaining old customers, attracting more and more new customers. Many studies have demonstrated that every $5 \%$ of customer retention rate will increase profits from 25-95\% profit (Reichheld, 1996; Reichheld $\&$ Sasser, 1990). Because according to the concept of modern marketing, "customers are king" and shopping services at supermarkets are no exception. As the society grows, the demands and desires of customers for supermarkets are also increasingly advanced and seen in many angles.

Parasuraman \& ctg (1985) presented a model of service quality. Parasuraman \& ctg (1985) stated that, any service, the quality of service perceived by customers by 10 components.

Table 1. Relationship between 2 models of Parasuraman (1985) and (1988)

\begin{tabular}{|l|l|}
\hline \multicolumn{1}{|c|}{ Original mode (1985) } & \multicolumn{1}{c|}{ Calibration model (1988) } \\
\hline Reliability & Reliability \\
\hline Responsiveness & Responsiveness \\
\hline Tangibles & Tangibles \\
\hline Reponsiveness & Reponsiveness \\
Courtesy & \\
Credibilit & \\
Security & \\
\hline Access & Empathy \\
Comunication & \\
Understanding customer & \\
\hline
\end{tabular}

Source: Parasuraman (1985) and (1988) 
The above 10-component model of service quality has the advantage of covering almost every aspect of the service. However, this model is relatively long and will cause complications in measurement. Moreover, in this theoretical model, there may be many components of this service quality model that do not reach discriminatory value. Therefore, on the basis of the existing theoretical model, the study has proposed a service quality model of 5 components. In other words, factors affecting customer satisfaction with supermarkets include:

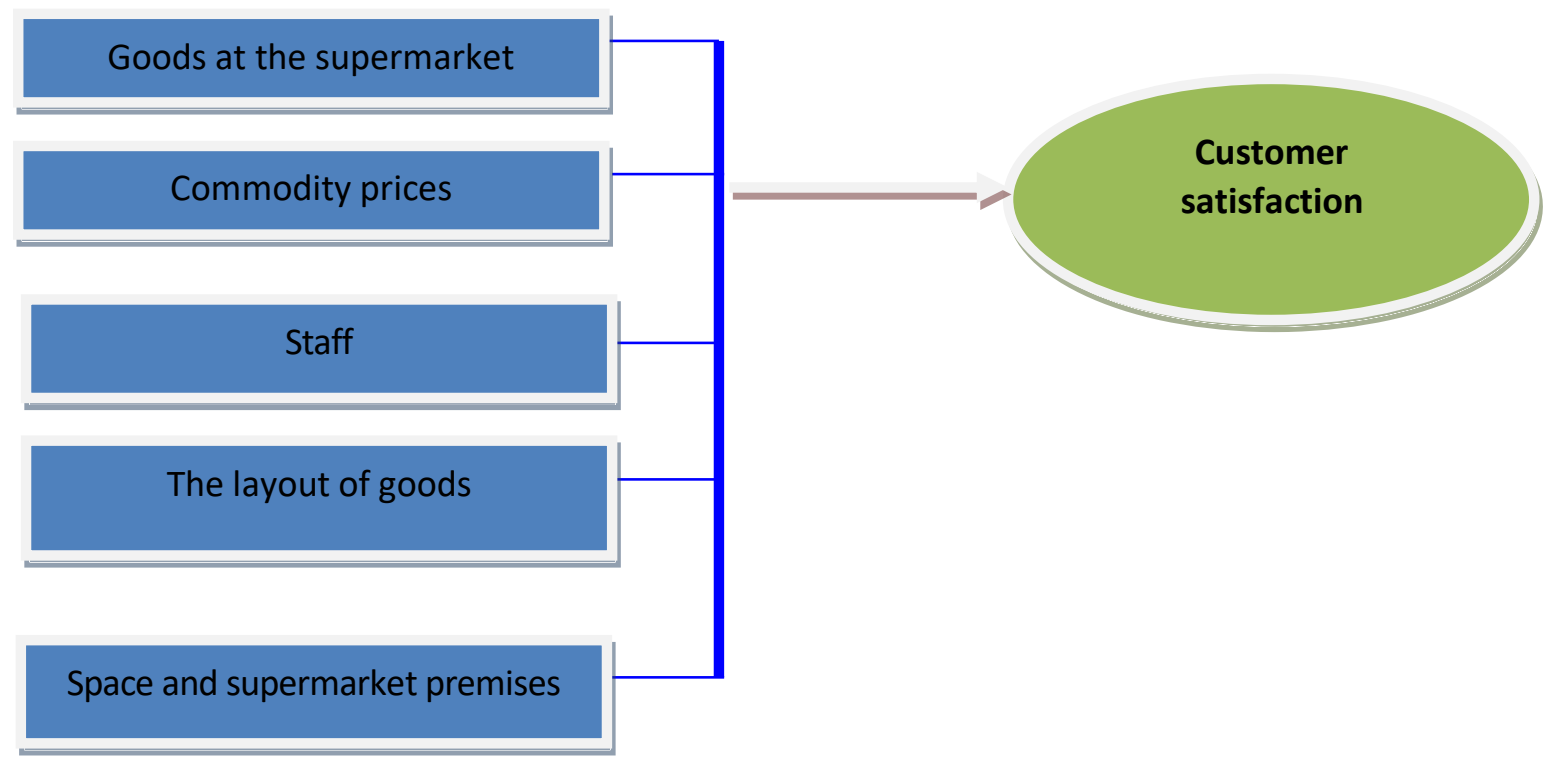

Figure 1. Proposed research model

Source: author construction

\section{Research Methods}

The paper uses survey method by form, using standardized questionnaire format and defining answer options in the questionnaire. Then, send out the questionnaire to the email available and via google form. The objective of this study is to provide specific data, so that decision makers can accurately predict the relationship between the factors to be studied and have a more comprehensive view of the research problem. The study was conducted with a sample of 150 questionnaires assessing customer satisfaction at the supermarket by the survey method.

- Method by questionnaire: The questionnaire is built to collect information to run models and test hypotheses.

- Sampling method: Non-probability sampling is selected according to subjective indications of the researcher. The total sample of the author survey is 150 samples.

- Testing the reliability of the scale by Cronbach's Alpha coefficient. Cronbach's alpha reliability test is used to eliminate trash variables before performing factor analysis. Testing the reliability of variables in the scale of supermarket service quality, customer satisfaction and customer loyalty at the supermarket based on Cronbach's Alpha test coefficient of scale components and Cronbach's Alpha coefficient of each measurement variable.

- Exploratory Factor Analysis (EFA). Exploratory Factor Analysis (EFA) The exploratory factor method is used to identify groups of criteria to evaluate service quality at supermarkets. The EFA analysis method belongs to an interdependence technique, that is, 
there are no independent and dependent variables, but it is based on the interrelationships. EFA is used to shorten a set of $\mathrm{k}$ variables into a set $\mathrm{F}(\mathrm{F}<\mathrm{k})$ of more significant factors. The basis of this reduction is based on the linear relationship of factors with observed variables.

- Confirmation factor analysis (Confirmatory Factor Analysis - CFA). Affirmative factor analysis) is one of the statistical techniques of linear structure model (SEM). CFA lets us test how well the measured variables represent constructs. CFA is the next step of EFA because CFA is only used appropriately when the researcher has some knowledge of the underlying underlying structure, in which the relationship or hypothesis (derived from theory or experiment). Between the observed variable and the baseline factor, it is assumed by the researcher before conducting statistical testing. CFA method is used to confirm the univariate, multivariate, convergence and discrimination values of the service quality assessment scale at the supermarket.

\section{Building a Scale and Research Process}

To assess customer satisfaction with supermarket services, a research model with 5 components: (1) Merchandise; (2) Price; (3) Employees; (4) Display; (5) Space. Specific observed variables are measured on a 5-level Likert scale used to rank from small to large, with the larger the number the higher the satisfaction level (1-Very dissatisfied; 2Dissatisfied; ; 3- Confused; 4- Satisfied; 5-Very satisfied). In addition to the above scales, the study also uses additional identification and hierarchical scales to screen the interviewees and collect personal information of the interviewees such as: Gender, income, occupation. age, address and address.

The research process is carried out in the following order:

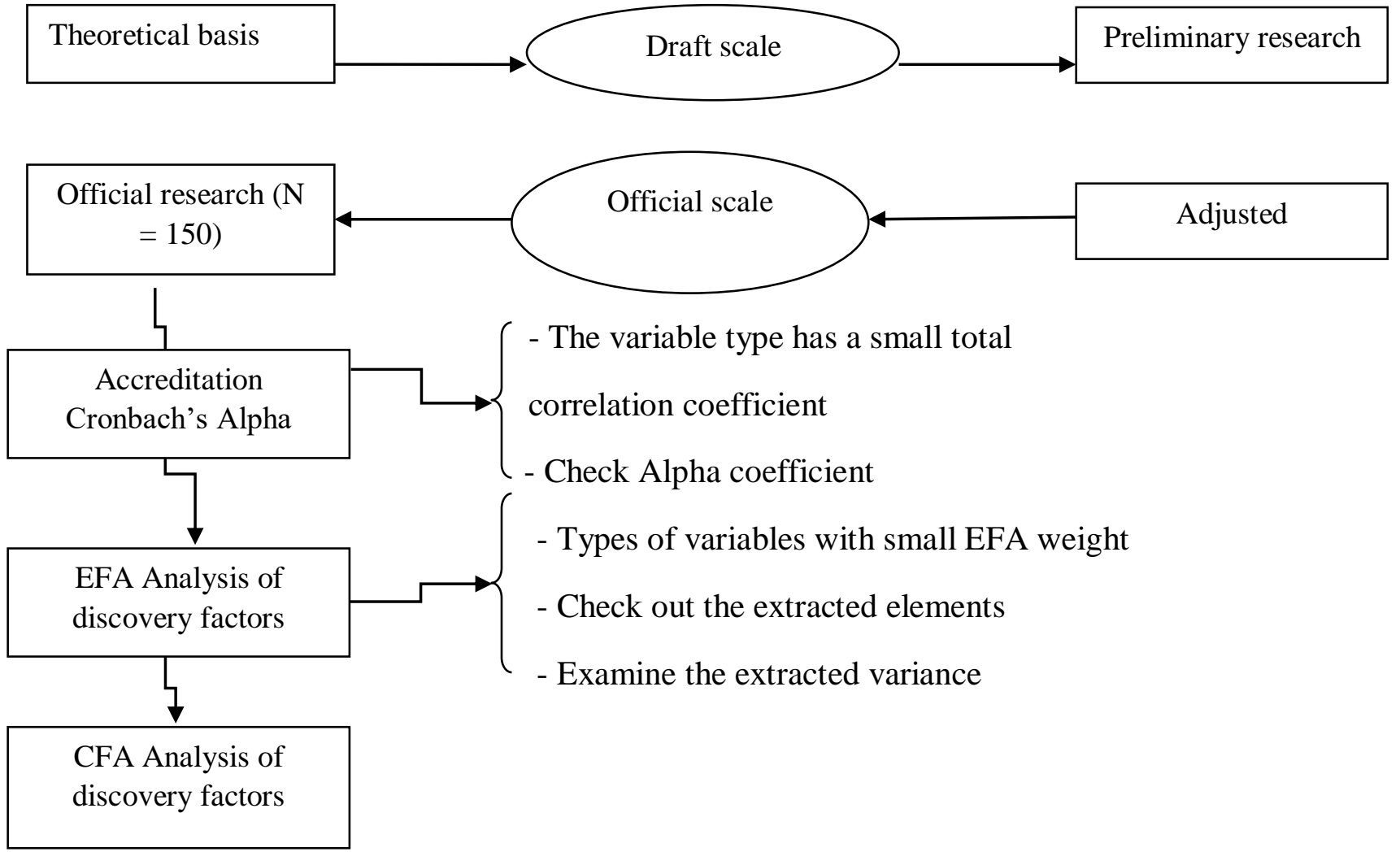

Figure 2. Research process

Source: author construction 


\section{Discussion}

\section{Anallysis resullts}

\subsection{Assess the reliability of the scale with Cronbach's Alpha coefficient}

Cronback's alpha coefficient is the correlation coefficient of the sum. Meaning is to reflect the degree of correlation of observed variables in a factor, the correlation towards the factor. The greater the cronback's alpha value, the greater the correlation. At least $>0.7$. Total correlation value: Create a distinction between high and low value groups. Cronback's alpha if item Delete (correlation coefficient of the sum if the observed variable is removed). This value must be smaller than the general cronback's alpha value.

\section{Goods at the supermarket}

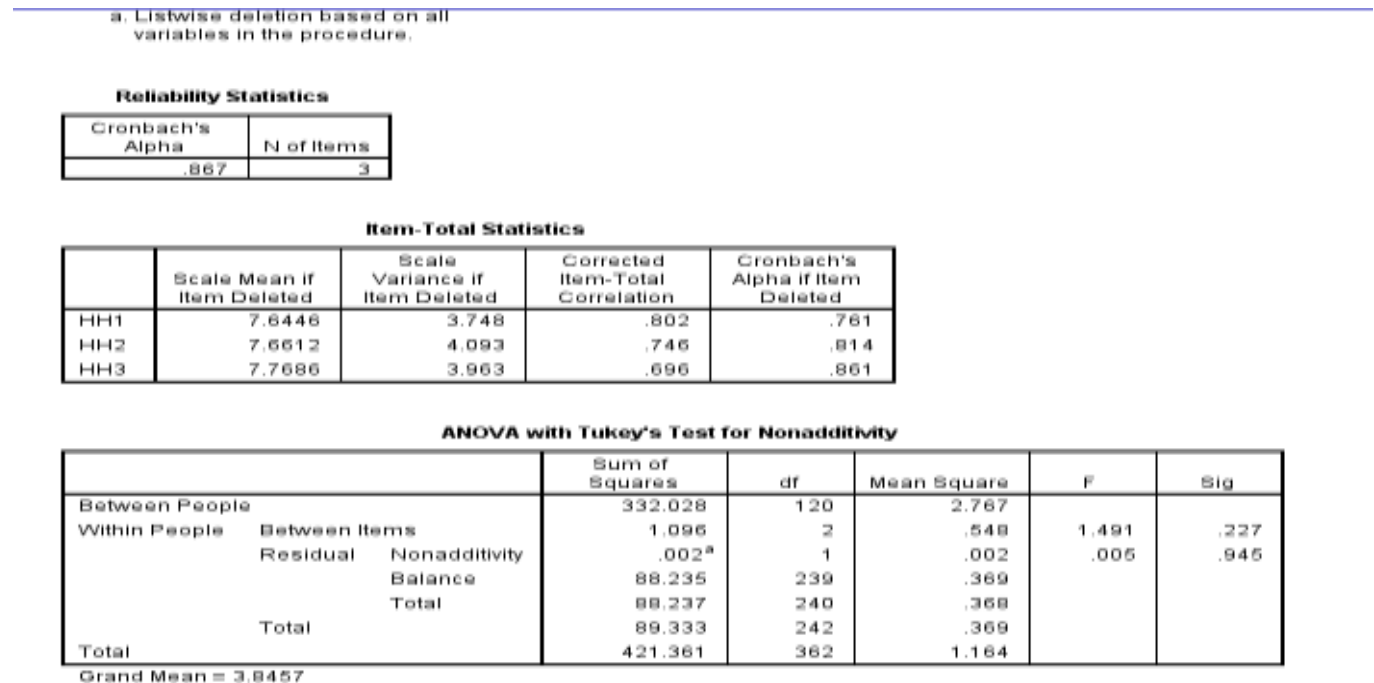

Figure 3. Cronbach's Alpha results Scale goods at the supermarket

In the Commodity factor, the cronback's alpha coefficient is $0.867>0.7$ so the observed variables in a factor are strongly correlated. The correlation coefficients of variables are 0.802 respectively; $0.746 ; 0.696>0.3$. Cronback's alpha if item Delete coefficient is 0.761 ; $0.814 ; 0.961<0.876$ (common cronback's alpha coefficient) should accept observed variables of commodity factors.

\section{Factor Staff}

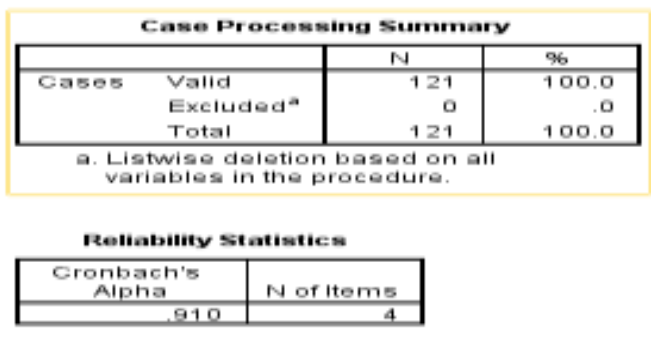

\begin{tabular}{|c|c|c|c|c|}
\hline & $\begin{array}{l}\text { Scale Mean if } \\
\text { Item Deleted }\end{array}$ & $\begin{array}{c}\text { Scale } \\
\text { Variance if } \\
\text { Item Deleted }\end{array}$ & $\begin{array}{l}\text { Corrected } \\
\text { item-Total } \\
\text { Correlation }\end{array}$ & $\begin{array}{c}\text { Oronbach's } \\
\text { Alpha if item } \\
\text { Deloted }\end{array}$ \\
\hline NV1 & 9.8017 & 7,994 & .675 & .923 \\
\hline$N V 2$ & 9.8430 & 7.050 & .843 & .866 \\
\hline NVa & 9.8017 & 6.927 & 832 & .870 \\
\hline NV4 & 9.8017 & 7.060 & 838 & 868 \\
\hline
\end{tabular}

Figure 4. Cronbach's Alpha results Employee scale 
In the Employee factor, the cronback's alpha coefficient is $0.910>0.7$ so the observed variables in a factor are strongly correlated. The correlation coefficients of the variable are respectively $0.675 ; 0.843 ; 0.832 ; 0.838>0.3$. Cronback's alpha if item Delete coefficient is $0.923 ; 0.866 ; 0.870 ; 0.868$. In the observed variable NV1, the coefficient Cronback's alpha if item Delete is greater than the common cronback's alpha coefficient so we remove this observation variable and accept the remaining observed variables.

\section{Factors the layout of goods}

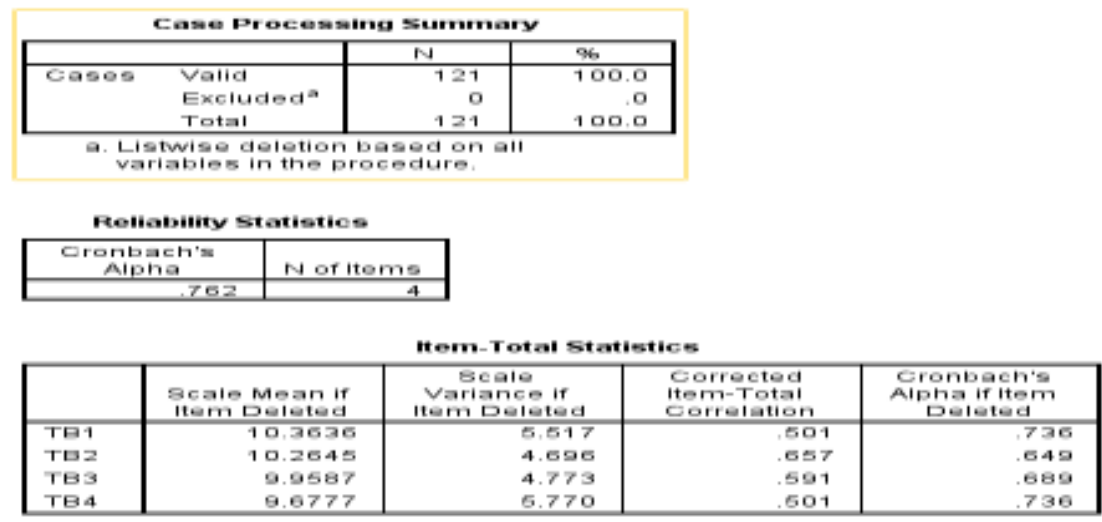

Figure 5. Cronbach's Alpha results Scale Display of goods

\section{Space and supermarket premises}

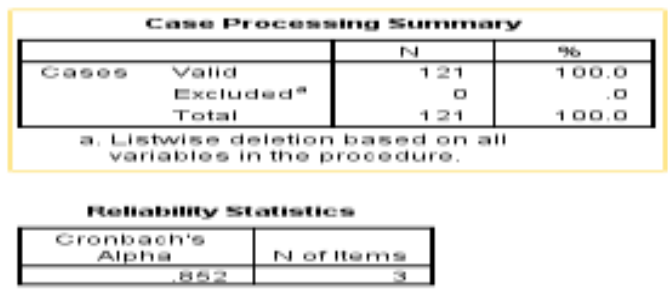

\begin{tabular}{|c|c|c|c|c|}
\hline & $\begin{array}{l}\text { acale Mean if } \\
\text { item Doloted }\end{array}$ & $\begin{array}{c}\text { Ecale } \\
\text { variance if } \\
\text { itempoleted }\end{array}$ & $\begin{array}{l}\text { Corrected } \\
\text { itsm-Total } \\
\text { corrolation } \\
\end{array}$ & $\begin{array}{c}\text { Cronbach's } \\
\text { Alphaif item } \\
\text { Deistod } \\
\end{array}$ \\
\hline ME1 & 7.2893 & 3.074 & .691 & 923 \\
\hline MB2 & 7.2397 & 2.834 & .766 & .762 \\
\hline ME3 & 7.1736 & 2.795 & .713 & 804 \\
\hline
\end{tabular}

Figure 6. Cronbach's Alpha results Scale of space and supermarket floor

\section{Price factors of goods}

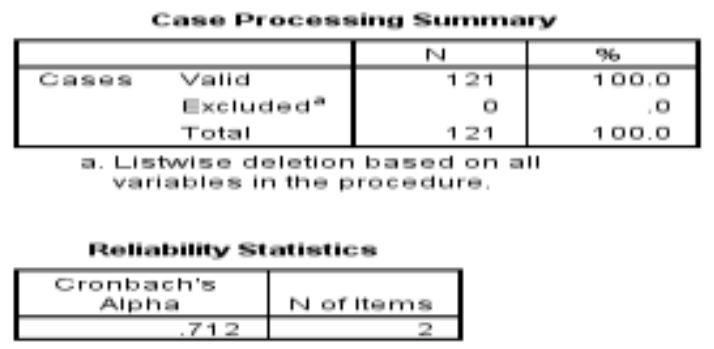

\begin{tabular}{|c|c|c|c|c|}
\hline & $\begin{array}{l}\text { Scale Mean if } \\
\text { item Deleted }\end{array}$ & $\begin{array}{c}\text { Scale } \\
\text { Variance if } \\
\text { itemDeleted }\end{array}$ & $\begin{array}{l}\text { Corrected } \\
\text { Itom-Total } \\
\text { Correlation } \\
\end{array}$ & $\begin{array}{c}\text { Cronbach's } \\
\text { Alpha if Item } \\
\text { Deleted }\end{array}$ \\
\hline AT1 & 3.3636 & 1.033 & .553 & \\
\hline AT2 & 3.5620 & 965 & 553 & \\
\hline
\end{tabular}

Figure 7. Cronbach's Alpha results a commodity price scale 
Similar to the Display, Space and Price factors, cronback's alpha coefficients are all eligible $>0.7$. Cronback's alpha coefficient if item Delete is less than the general cronback's alpha coefficient. The observed variables are reliable and should be accepted.

\subsection{Analysis of EFA discovery factors}

When running the factor analysis, EFA did not reuse the variables removed in cronback's alpha test.

In EFA factor analysis, only the independent variables' discoverable factors are included in the analysis and no general assessment is included.

\section{KMO and Bartlett's Test}

\section{KMO and Bartlett's Test}

\begin{tabular}{|ll|r|}
\hline Kaiser-Meyer-Olkin Measure of Sampling Adequacy. & .720 \\
Bartlett's Test of & Approx. Chi-Square & 880.228 \\
Sphericity & df & 105 \\
& Sig. & .000 \\
\hline
\end{tabular}

Figure 8. KMO and Bartlett's Test Results

KMO coefficient $=0.720>0.5$. Therefore, factor analysis is appropriate for the research data

Bartlett's Test result is 880.228 with significance level sig $=0.000<0.05$ so the hypothesis of factor model is inappropriate and will be rejected, this proves that the data used for factor analysis is complete. Full appropriate.

\section{Total Variance Explained}

Table 2. Extraction variance results

Total Variance Explained

\begin{tabular}{|c|c|c|c|c|c|c|c|c|c|}
\hline \multirow[b]{2}{*}{ Factor } & \multicolumn{3}{|c|}{ Initial Eigenvalues } & \multicolumn{3}{|c|}{ Extraction Sums of Squared Loadings } & \multicolumn{3}{|c|}{ Rotation Sums of Squared Loadings } \\
\hline & Total & $\%$ of Variance & Cumulative $\%$ & Total & $\%$ of Variance & Cumulative $\%$ & Total & $\%$ of Variance & Cumulative $\%$ \\
\hline 1 & 3.639 & 24.261 & 24.261 & 3.376 & 22.507 & 22.507 & 2.501 & 16.676 & 16.676 \\
\hline 2 & 2.977 & 19.849 & 44.110 & 2.642 & 17.613 & 40.120 & 2.109 & 14.057 & 30.733 \\
\hline 3 & 1.921 & 12.808 & 56.919 & 1.547 & 10.313 & 50.433 & 2.070 & 13.799 & 44.532 \\
\hline 4 & 1.557 & 10.377 & 67.296 & 1.140 & 7.600 & 58.033 & 1.887 & 12.578 & 57.110 \\
\hline 5 & 1.305 & 8.703 & 75.999 & 1.024 & 6.825 & 64.858 & 1.162 & 7.748 & 64.858 \\
\hline 6 & .715 & 4.769 & 80.768 & & & & & & \\
\hline 7 & .550 & 3.667 & 84.434 & & & & & & \\
\hline 8 & .445 & 2.966 & 87.400 & & & & & & \\
\hline 9 & .413 & 2.756 & 90.155 & & & & & & \\
\hline 10 & .389 & 2.592 & 92.747 & & & & & & \\
\hline 11 & .309 & 2.059 & 94.806 & & & & & & \\
\hline 12 & .258 & 1.717 & 96.523 & & & & & & \\
\hline 13 & .214 & 1.430 & 97.953 & & & & & & \\
\hline 14 & .192 & 1.280 & 99.233 & & & & & & \\
\hline 15 & .115 & .767 & 100.000 & & & & & & \\
\hline
\end{tabular}


The results show that the scales were initially grouped into groups

- The value of the total variance extracted $=64.858 \%>50 \%$ is required, then it can be said that the independent scales explain $64.858 \%$ of the data variation.

- Eigenvaluaes coefficient value $=1.305$.

Table 3. Results of the factor rotation matrix

\begin{tabular}{|c|c|c|c|c|c|}
\hline \multicolumn{6}{|c|}{ Rotated Factor Matrix ${ }^{a}$} \\
\hline & \multicolumn{5}{|c|}{ Factor } \\
\hline & 1 & 2 & 3 & 4 & 5 \\
\hline NV3 & .905 & & & & \\
\hline NV4 & .903 & & & & \\
\hline $\mathrm{NV} 2$ & .810 & & & & \\
\hline $\mathrm{HH} 1$ & & .908 & & & \\
\hline $\mathrm{HH} 2$ & & .814 & & & \\
\hline $\mathrm{HH} 3$ & & .729 & & & \\
\hline MB2 & & & .909 & & \\
\hline MB3 & & & .742 & & \\
\hline MB1 & & & .711 & & \\
\hline TB2 & & & & .791 & \\
\hline TB3 & & & & .695 & \\
\hline TB4 & & & & .584 & \\
\hline TB1 & & & & .584 & \\
\hline AT2 & & & & & .780 \\
\hline AT1 & & & & & .720 \\
\hline
\end{tabular}

From the factor rotation matrix, it is shown that the initial 16 independent scales are of practical significance (>0.5) and are aggregated into 5 factors.

\subsection{Testing the scale by CFA confirmatory factor analysis method}

Table 4. Results of rotating values of load factors

\begin{tabular}{|c|c|c|c|c|c|c|c|}
\hline \multicolumn{8}{|c|}{ Pattern Matrix a } \\
\hline & \multicolumn{7}{|c|}{ Factor } \\
\hline & 1 & 2 & 3 & 4 & 5 & 6 & 7 \\
\hline NV3 & .942 & & & & & & \\
\hline NV4 & .932 & & & & & & \\
\hline NV2 & .798 & & & & & & \\
\hline SHL4 & & .772 & & & & & \\
\hline SHL2 & & .758 & & & & & \\
\hline SHL3 & & .704 & & & & & \\
\hline SHL5 & & .546 & & & & & \\
\hline SHL1 & & .544 & & & & & \\
\hline $\mathrm{HH} 1$ & & & .942 & & & & \\
\hline $\mathrm{HH}_{2}$ & & & .863 & & & & \\
\hline $\mathrm{HH}_{3}$ & & & .710 & & & & \\
\hline MB2 & & & & 999 & & & \\
\hline MB1 & & & & .716 & & & \\
\hline MB3 & & & & .692 & & & \\
\hline TB2 & & & & & .811 & & \\
\hline TB3 & & & & & .708 & & \\
\hline TB1 & & & & & .597 & & \\
\hline TB4 & & & & & .574 & & \\
\hline AT1 & & & & & & .891 & \\
\hline AT2 & & & & & & .606 & \\
\hline TTST1 & & & & & & & .851 \\
\hline TTST2 & & & & & & & .659 \\
\hline
\end{tabular}




\section{CFA results}

The results of the CFA affirmation analysis showed that: Chi-square / df $=1,194<2$, $\mathrm{CFI}=0.977$, GFI $=0.883$ very close to 0.9 , RMSEA index $=0.036<0.08$. From the above indicators prove the model is consistent with market data.

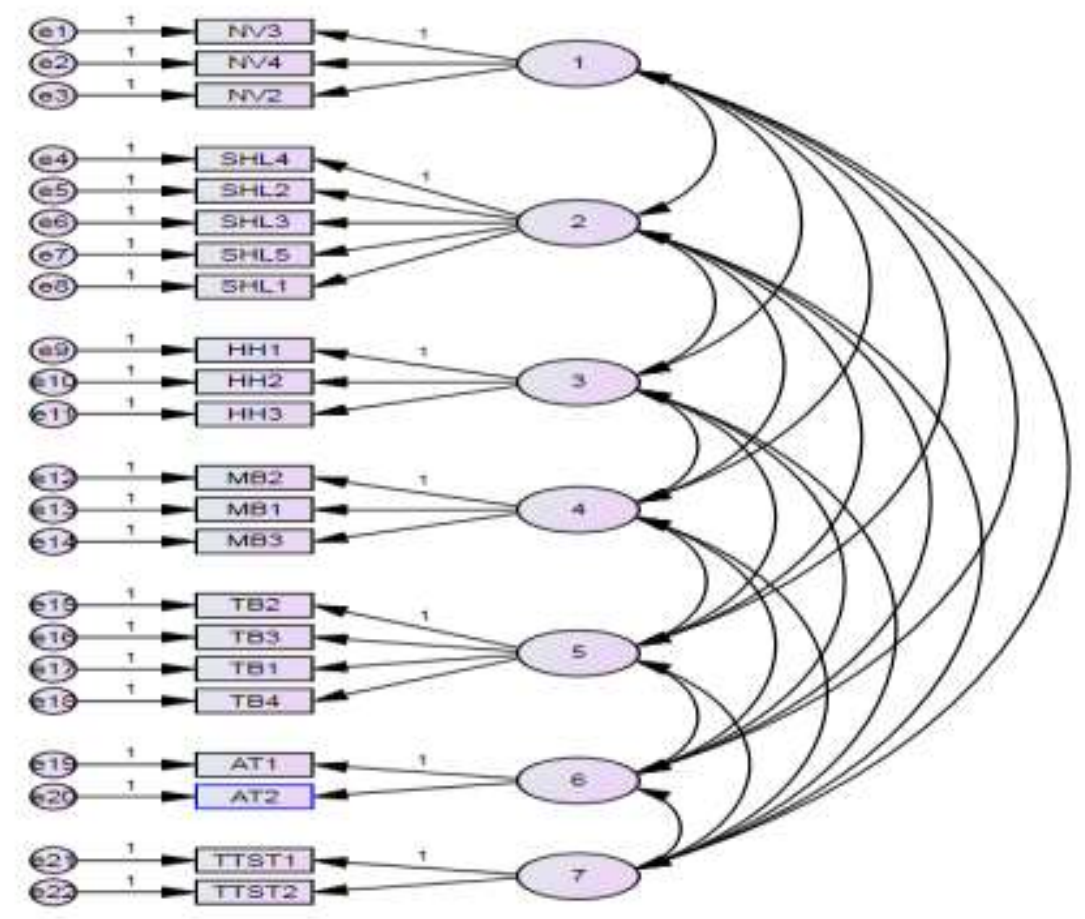

Figure 9. CFA results of the scale of supermarket service quality (standardized)

\section{Conclusion}

The introduction of a customer satisfaction test model for service quality at retail supermarkets helps us have a visual look in business performance analysis and evaluation. In addition, it helps managers realize the urgency in attracting customers to improve business efficiency at the supermarket. Since then, making appropriate management decisions for the development and expansion of production and business activities.

It can be said that the level of customer satisfaction is a measure of service quality, the study of customer satisfaction and the factors affecting satisfaction when using the services here are necessary. Set, has a particularly important meaning. The results of this exercise help managers, supermarket leaders evaluate the ability to meet the expected values of customers, identify the achieved and limited and more important aspects. It is to identify the factors that need to be improved in the coming time to further improve the quality of supermarket services, retain old customers and attract new customers.

From the results of the customer rating on the Likert scale presented, we have an objective view of customer satisfaction for each factor as well as small observation variables, based on that result. Identify which issues the customers feel satisfied, the ones not satisfied. Therefore, in order to improve the overall satisfaction of customers, specific implementation solutions must be proposed to achieve that goal. Here are some suggested solutions:

Supermarkets need to complete the system of facilities, equipment, tools to provide services ... Arranging counters, shelves, convenient cabinets, goods arranged easily for customers' shopping choices. Space is clean and airy. Supermarkets should add ATMs of different banks, making it more convenient for customers to pay. 
The supermarket has a full staff of salespeople, cashiers, security guards ... to meet customer needs. The staff at the supermarket are mostly trained in the knowledge of commodity information, types of goods ... as well as basic communication skills...

The supermarket management board needs to check and evaluate objectively the spirit, working attitude and service of the employees in the supermarket. On that basis draws the limitations of staff in the process of customer service. There should be a welcoming, proper attitude; Listen well, always ready to serve. , always keep the positive service attitude with the motto "customer is god". Need to add uniforms for employees to contribute to the professionalism of the staff.

The supermarket's input check system needs to further improve its function as well as the task of selecting quality goods for sale in supermarkets. Regularly check the quality as well as the expiry date of goods sold and in stock. To promptly handle items that are about to expire and remove expired items from the stalls.

Through surveys and research, found that the service quality of supermarkets is relatively satisfied but not high. Therefore, in the coming time, the supermarket needs to try harder to attract and retain customers. In particular, the retail supermarkets also need to maintain the factors that satisfy customers such as goods, display, safety, premises to increasingly improve the quality of customer service.

\section{References}

Ademuyiwa J. A., Adetunji A. A. Impact of Some Economic Variables on the Real Gross Domestic Product of Nigeria. Budapest International Research and Critics Institute (BIRCI-Journal): Humanities and Social Sciences. Vol 2, No 4 (2019).

Ahmad Husin Siregar, Yusuf Hadijaya. Madrasah Headmaster Performance Strategy in Madrasah Al Washliyah 22 Tembung. Britain International of Humanities and Social Sciences, Vol 1 No 2 (2019).

Agus Dono Wibawanto. Legal Protection of Tobacco Farmers in Indonesia. Budapest International Research and Critics Institute (BIRCI-Journal): Humanities and Social Sciences. Vol 2, No 4 (2019).

Ashaduzzaman, Ahmed, S., Khan, M., 2011. Consumer choice behavior towards mobile phone operators in Bangladesh. Journal of Arts, Science \& Commerce, Vol. 2, 30-39.

Akbaba, A. (2006). Measuring service quality in the hotel industry: A study in a business hotel in Turkey. Hospitality Management, 25, 170-192.

Baker, D. A. \& Crompton, J. L. (2000). Quality, Satisfaction and Behavior Intentions. Annals of Tourism Research, 27 (3), 785-804.

Bitner, M. (1990). Evaluating Service Encounters: The Effects of Physical Surroundings and Employee Responses. Journal of Marketing, 54 (2), 69-82.

Cronin, J. \& Taylor, S. (1992). Measuring Service Quality: A Reexamination and Extension. Journal of Marketing, 56 (3), 55-68.

Czepiel, J. A., Solomon, M. R. \& Gutman, E. G. (1985). A role Theory Perspective on Dyadic Interaction: The Service Encounter. Journal of Marketing, 49 (1), 99-111.

Dabholkar, P., Thorpe, D. \& Rentz, J. (1996). A Measure of Service Quality for Retail Stores: Scale Development and Validation. Journal of the Academy of Marketing Science. 24 (1): 3-16.

Engle, J. F., Kegerreis, R. J. \& Blackwell, R. D. (1969). Word-of-mouth Communication by the Innovator. Journal of Marketing, 33, 15-19. 
Gerbing, D. W. \& Anderson, J. C. (1988). An Updated Paradigm for Scale Development Incorporating Unidimensionality and Ít Assessment. Journal of Marketing Research 25 (2): 186-192.

Chai, Ding, and Xing, 2009. Quality and customer satisfaction spillovers in the mobile phone industry. Journal of Service Science, Vol. 1, 93-106.

Chen, C. (2008). Investigating structural relationship between service quality, perceived value, satisfaction, and behavioral intentions for air passengers: Evidence from Taiwan. Transportation Research, 42 (A), 709-717.

Chuttur, M.Y., 2009. Overview of the Technology Acceptance Model: Origins, Developments and Future Directions. Sprouts: Working Papers on Information Systems, 9(37).

Chen, Y., Hsieh, T. (2005). Correlation of service quality of Hot Spring Hotels, customer satisfaction, customer loyalty and life style. Fourth Annual Asia Pacific forum for graduate students research in Tourism, Hawaii, United States, 1-3 August, 2005.

Haquea, A., Rahman, S., Rahman, M., 2010. Factors eterminants the Choice of Mobile Service Providers: Structural Equation Modeling Approach on Bangladeshi Consumers. Business and Economics Research Journal, Vol. 1, No. 3, 17-34.

Hang Nguyen Thi. Research on a number of applicable forecasting techniques in economic analysis, supporting enterprises to decide management. International Scientific Journal, WSN 119 (2019) 52-67.

Hang Nguyen Thi, Huan N.V. Research system for management of wages and applications in management of wages in Vietnamese enterprises. International Journal of Applied Science and Research, 2019 VOL.2 ISSU.1.

Henry, B., Quansah, M.K., 2013. Mobile telecommunication networks choice among Ghanaians. Management Science Letters, 1839-1850.

Karacuka, M., Catik, N., Haucap, J., 2013. Consumer Choice and Local Network Effects in Li Bing-quan, Hu Rong, Du Hai-xin, Zhang Xu-dong. Analysis on Behavior Factors of Successful Entrepreneurship of College Students of Local University in Guangdong Province. Britain International of Humanities and Social Sciences, Vol. 2, No. 1(2020).

Mobile Telecommunications in Turkey. Telecommunications Policy, Vol. 37, 334-344.

Kim, M.K, Park, M.C., Jeong, D.H., 2004. The effects of switching barrier on customer loyalty in Korean mobile telecommunication services. Telecommunications Policy, Vol. 29, 145-159.

Mehta, S. C., Ashok Lawani \& Soon Li Han (2000). Service Quality in Retailing: Relative Eficiency of Alternative Measurement Scales for Different Product-service Environments. International Journal of Retail \& Distribution Management. 28 (2): 6272.

Mazzonia, C., Castaldia, L., Addeo, F., 2007. Consumer behavior in the Italian mobile telecommunication market. Telecommunications Policy, Vol. 31, No. 10, 632-647.

Olatokun, W., Nwone, S.A., 2012. Determinants of users' choice of mobile service providers in the Nigerian telecommunications market. African Journal of Computing \& ICT, Vol. 5, No. 4, 19- 32.

Olatokun, W., Nwone, S.A., 2013. Influence of socio-demographic variables on users"choice of mobile service providers in Nigerian telecommunication market. International Journal of Computer and Information Technology, Vol. 2, 888-894. 